\title{
Purification of the pancreatic cholecystokinin receptor
}

\author{
J. Szecowka ${ }^{1, *}$, G. Hallden ${ }^{1}$, I.D. Goldfine ${ }^{1,2}$ and J.A. Williams ${ }^{1-3}$ \\ ${ }^{1}$ Cell Biological Laboratory, Mount Zion Hospital and Medical Center, San Francisco, CA 94120 \\ (U.S.A.), ${ }^{2}$ Departments of Physiology and Medicine, University of California, San Francisco, CA 94143 \\ (U.S.A.) and ${ }^{3}$ Departments of Physiology and Medicine, University of Michigan, Ann Arbor, MI 48109 \\ (U.S.A.)
}

(Received 23 September 1988; revised version received and accepted 31 October 1988)

\section{Summary}

We have previously shown that the pancreatic cholecystokinin (CCK) receptor can be solubilized in $1 \%$ digitonin. In this study, digitonin-solubilized CCK receptors from rat pancreas were purified using sequential affinity chromatography on ricin-II agarose and on AffiGel-CCK. Electrophoresis of the radioiodinated purified receptors on SDS-polyacrylamide gels followed by autoradiography revealed two proteins: a major band of $M_{\mathrm{r}}=80,000-90,000$, and a minor band of $M_{\mathrm{r}}=55,000$. Through the purification procedure, the receptors preserved their agonist specificity (CCK-8 < CCK-33 < desulfated CCK-8 < CCK-4) and binding affinity. Scatchard transformations of binding data for the purified receptor preparation were best fit by linear plots compatible with a single class of binding sites with $K_{\mathrm{d}}=9.4 \mathrm{nM}$. The estimated purification was about 80,000 fold and consistent with the expected $B_{\max }$ for a pure $M_{\mathrm{r}}=80,000$ protein binding one CCK molecule. This two-step purification procedure opens the possibility for molecular studies of the CCK receptor.

Cholecystokinin; Purification; Sequence determination

\section{Introduction}

Cholecystokinin (CCK) released from duodenal endocrine cells acts on a number of target organs including the exocrine and endocrine pancreas, gall bladder, and

* Present address: Catholic University of Chile, Santiago, Chile.

Correspondence: J.A. Williams, Department of Physiology, 7744 Medical Science II, University of Michigan, Ann Arbor, Michigan 48109-0622, U.S.A. 
stomach [1-4]. These peripheral actions of CCK are initiated by binding to a receptor whose binding affinity, agonist and antagonist specificity and $\mathrm{pH}$ optimum have been characterized [5-9]. These studies indicate that there is a peripheral CCK receptor which is distinct from both the central nervous system CCK receptor [10] and the peripheral gastrin receptor. Peripheral CCK receptors have been best studied on the pancreatic acinar cell where the binding subunit has an apparent molecular radius $\left(M_{\mathrm{r}}\right)$ of $76,000-95,000$ as demonstrated by affinity labeling studies [11-15]. Further, the receptor is a glycoprotein based on affinity for lectins and susceptibility to endoglycosidases $[13,14,16]$. Interpretation of these results is complicated, however, by the observation that different CCK receptor proteins appear to be labeled depending on the ${ }^{125}$ I-labeled CCK probe used [16].

Further characterization of the CCK receptor therefore requires its purification and sequence determination. The initial step in this process was the demonstration that the receptor could be solubilized by use of the detergent digitonin with retention of ability to specifically bind CCK [17]. In the present report we have used the ability to solubilize the CCK receptor to develop a purification scheme involving lectin and CCK affinity chromatography. This procedure results in a preparation having a major protein band of $M_{\mathrm{r}}=80,000-90,000$ in SDS gel electrophoresis which specifically binds CCK.

\section{Materials and Methods}

\section{Materials}

Pure natural porcine cholecystokinin (CCK-33) was obtained from Dr. V. Mutt, Karolinska Institute (Stockholm, Sweden). Synthetic CCK-8 and desulfated CCK-8 (d-CCK-8) were gifts from the Squibb Institute for Medical Research (Princeton, NJ). Soybean trypsin inhibitor (SBTI), benzamidine, bacitracin, phenylmethylsulfonyl fluoride (PMSF), HEPES, lactose, ethanolamine, human $\gamma$-globulin (HG-II) and urea were purchased from Sigma Chemical Co. (St. Louis, MO); bovine serum albumin (BSA) fraction $\mathrm{V}$ from Miles Laboratories (Elkhart, IN); ${ }^{125}$ I-Bolton Hunter Reagent $(2000 \mathrm{Ci} / \mathrm{mmol})$ from New England Nuclear (Boston, MA); polyethylene glycol (PEG-6000), and digitonin (AnalaR) from BDH Chemicals Ltd. (Poole, U.K.); agarose bound lectins (wheat germ, ricin II, lentil, concanavalin A, peanut, and lotus) from E.Y. Laboratories, Inc. (San Mateo, CA); molecular weight standards for gel electrophoresis, and dithiothreitol (DTT) from Bio Rad Laboratories (Richmond, CA). Sprague-Dawley male rats, weighing $250-350 \mathrm{~g}$, were killed by decapitation.

\section{Methods}

Solubilization of the CCK receptor. Routinely, pancreases from 32 rats were minced and homogenized by use of a Polytron homogenizer (Brinkmann Instruments, Westbury, NY) in $100 \mathrm{ml}$ ice cold 'solubilization buffer' containing: $50 \mathrm{mM}$ HEPES (pH 7.4), $150 \mathrm{mM} \mathrm{NaCl}, 5 \mathrm{mM} \mathrm{MgCl}_{2}, 1 \mathrm{mM}$ EGTA, $1 \mathrm{mM}$ benzamidine, and $0.1 \mathrm{mM}$ PMSF, to which $1 \%(\mathrm{w} / \mathrm{v})$ digitonin was added. Solubilization was carried out for $1 \mathrm{~h}$ at $4^{\circ} \mathrm{C}$. Alternatively, plasma membranes prepared from isolated pancreatic acini as 
described previously [18] were solubilized in the aforementioned "solubilization buffer" with $1 \%$ digitonin for $1 \mathrm{~h}$ at $4^{\circ} \mathrm{C}$ in a glass test tube rotating 12 times per min, as described previously [17]. Protein concentrations, unless stated otherwise, were assayed by the Lowry method [19] using BSA as standard.

All subsequent operations were also carried out at $4^{\circ} \mathrm{C}$. The solubilized material was centrifuged at $110,000 \mathrm{~g}$ for $1 \mathrm{~h}$, the supernatant collected, diluted to a final digitonin concentration of $0.5 \%$, and used either for purification or directly stored frozen at $-70^{\circ} \mathrm{C}$.

Radioligand binding assay. CCK-33 was labeled with ${ }^{125} \mathrm{I}$ by conjugation with ${ }^{125}$ I-Bolton Hunter reagent with a resulting spec. act. of $200-300 \mathrm{Ci} / \mu \mathrm{g}$; determination of tracer CCK concentration was by bioassay employing rat or mouse pancreatic acini [20,21]. Binding experiments were performed in a total volume of $250 \mu \mathrm{l}$, as described previously [17]. Briefly, the incubation buffer consisted of $118 \mathrm{mM} \mathrm{NaCl}$, $4.7 \mathrm{mM} \mathrm{KCl}, 5 \mathrm{mM} \mathrm{MgCl}$, $1 \mathrm{mM}$ EGTA, $5 \mathrm{mg} / \mathrm{ml} \mathrm{BSA}, 1 \mathrm{mg} / \mathrm{ml}$ bacitracin, and 0.2 $\mathrm{mg} / \mathrm{ml}$ SBTI. Routinely, $50 \mu \mathrm{l}$ aliquots of solubilized material containing CCK receptors were incubated in a total volume of $250 \mu \mathrm{l}$ with $50 \mathrm{pM}{ }^{125} \mathrm{I}-\mathrm{CCK}$ for $16 \mathrm{~h}$ at $4^{\circ} \mathrm{C}$ and $\mathrm{pH}$ 6.5; CCK-8 was added at $1 \mu \mathrm{M}$ to determine non-specific binding. Both total and non-specific binding were determined in duplicate tubes. After incubation, the receptor-CCK complex was precipitated by addition of an equal volume of $20 \%$ (w/v) PEG. Human $\gamma$-globulin (final conc. $0.5 \mathrm{mg} / \mathrm{ml}$ ) was present as carrier, and potassium iodide (final conc. $2.5 \mathrm{mg} / \mathrm{ml}$ ) was added to reduce trapping of radioactivity. Samples were centrifuged at $2000 \mathrm{~g}$ for $30 \mathrm{~min}$, the supernatants removed, and the pellets counted in a gamma-scintillation counter. Values are reported as the percent of added ${ }^{125} \mathrm{I}-\mathrm{CCK}$ which is specifically bound (i.e., total binding minus non-specific binding). Non-specific binding as in previous work [17] was essentially all accounted for by trapping of ${ }^{125} \mathrm{I}-\mathrm{CCK}$ in the PEG precipitated pellet and varied from 6 to $9 \%$ of added radioactivity.

Affinity chromatography on agarose bound lectins. Lectins were equilibrated with 'solubilization buffer' containing $0.5 \%$ digitonin. Samples of solubilized material were slowly passed through one of 6 different lectin-agarose columns: concanavalin A (Con A), lentil, peanut, lotus, wheat germ, and ricin II (RC-II). The columns were then washed, and the adsorbed material was eluted with the same buffer, containing specific haptenic inhibitors (sugars) at a concentration of $200 \mathrm{mM}$. Con A and lentil lectin were eluted with glucose, peanut lectin with galactose, lotus lectin with fucose, wheat germ with $\mathrm{N}$-acetyl-D-glucosamine, and RC-II with lactose. Fractions were assayed for specific CCK binding. Peak fractions of partially purified receptors were stored at $-70^{\circ} \mathrm{C}$.

Affinity chromatography on AffiGel-CCK. Three mg of CCK-8 were dissolved at 1 $\mathrm{mg} / \mathrm{ml}$ in $50 \mathrm{mM}$ borate, $\mathrm{pH} 9.3$. Two $\mathrm{ml}$ of Affigel-15 were added and coupling was carried out in a $13 \times 100 \mathrm{~mm}$ glass test tube rotating 3 times per min at $4^{\circ} \mathrm{C}$ for $6 \mathrm{~h}$. The coupling was stopped by quenching with $10 \mu \mathrm{l} / \mathrm{ml}$ of ethanolamine. AffiGel CCK was then washed and equilibrated with 'solubilization buffer' plus $0.5 \%$ digitonin. To assess efficiency, $100 \mu \mathrm{l}$ aliquots of the CCK-8 solution before and after coupling were diluted with $300 \mu \mathrm{l}$ of $50 \mathrm{mM}$ borate, the $\mathrm{pH}$ was brought down to 1.9 by adding $64 \mu \mathrm{l}$ of $1 \mathrm{~N} \mathrm{HCl}$, and concentrations of CCK- 8 were assayed by measuring 
$\mathrm{OD}_{280}$, with D-CCK-8 as standard. Coupling efficiency was $34 \pm 6 \%(n=3)$. Subsequently, AffiGel-CCK was incubated batchwise with $8 \mathrm{ml}$ of the CCK receptor solution (partially purified on RC-II agarose) for $6 \mathrm{~h}$ at $4^{\circ} \mathrm{C}$ in a $13 \times 100 \mathrm{~mm}$ glass test tube rotating 3 times per min. During this incubation, between 80 and $100 \%$ of specific CCK binding activity was routinely adsorbed by the AffiGel-CCK. In control experiments, AffiGel alone quenched with ethanolamine did not adsorb any CCK binding activity. AffiGel-CCK-receptor complex was then washed 5 times by repeated centrifugation and resuspension in $8 \mathrm{ml}$ of 'solubilization buffer' containing $0.5 \%$ digitonin, and finally eluted with $2.0 \mathrm{ml}$ of $5 \mathrm{M}$ urea in the same buffer. The eluted material was then dialyzed for $15 \mathrm{~h}$ against $3 \times 200 \mathrm{ml}$ of the digitonin containing 'solubilization buffer' to remove urea, then assayed for specific CCK binding, and stored at $-70^{\circ} \mathrm{C}$.

Iodination, electrophoresis, and autoradiography. Purified receptors were iodinated by the chloramine T method [22]. Briefly, $200 \mu$ lof pure receptor preparation, $20 \mu \mathrm{l}$ of chloramine $\mathrm{T}(0.4 \mathrm{mg} / \mathrm{ml})$, and $200 \mu \mathrm{Ci}^{125} \mathrm{I}$ were incubated together at room temperature for $10 \mathrm{~min}$. Free iodine was then separated from iodinated proteins on a Sephadex G-25 column.

Samples were boiled in SDS sample buffer for $2 \mathrm{~min}$ in the presence of $50 \mathrm{mM}$ DTT[12]. Electrophoresis was performed according to Laemmli [23], using $1.5 \mathrm{~mm}$ thick slab gels $(12.5 \times 16 \mathrm{~cm})$ containing $7.5 \%$ acrylamide. After electrophoresis, the gels were stained with the BioRad Silver Stain (Bio Rad Laboratories, Richmond, CA). The apparent molecular weight was calculated by using as standards: myosin $\left(M_{\mathrm{r}}=200,000\right), \beta$-galactosidase $\left(M_{\mathrm{r}}=116,250\right)$, phosphorylase-B $\left(M_{\mathrm{r}}=92,500\right)$, bovine serum albumin $\left(M_{\mathrm{r}}=45,000\right)$. Autoradiograms were obtained after exposure of the gels to Kodak X-Omat AR film with DuPont Cronex Lightning Plus enhancing screen at $-70^{\circ} \mathrm{C}$.

\section{Results}

Partial purification of CCK receptors by lectin affinity chromatography

Initially, pancreatic acini were prepared from the pancreases of 4 rats, and plasma membranes (routinely about $2 \mathrm{mg}$ of protein) were purified by ultracentrifugation using sucrose gradients. The membranes were then solubilized at a concentration of 1 $\mathrm{mg}$ of protein $/ \mathrm{ml}$ with $1 \%$ digitonin (as described in Methods) yielding crude solubilized protein $\left(550 \pm 60 \mu \mathrm{g} / \mathrm{ml}\right.$ mean \pm S.E.M., $n=3$ ) with a specific ${ }^{125} \mathrm{I}$-CCK binding activity in our standard binding assay of $12 \pm 2 \%$ of total ligand added. Using this material the ability of 6 different agarose-bound lectins to adsorb CCK receptors was examined. All of these lectins adsorbed specific CCK binding activity (Fig. 1). However, only RC-II quantitatively adsorbed all of the CCK binding activity; this binding activity was recovered in the lactose eluate (Fig. 1). Therefore, we selected $\mathrm{RC}-\mathrm{II}$ as a tool in the further purification of the CCK receptors.

In order to 'scale up' the preparation of solubilized receptors, the procedure was then simplified by omitting two steps: preparation of acini and isolation of acinar plasma membranes. Now, 32 rats were decapitated and whole pancreases were solu- 


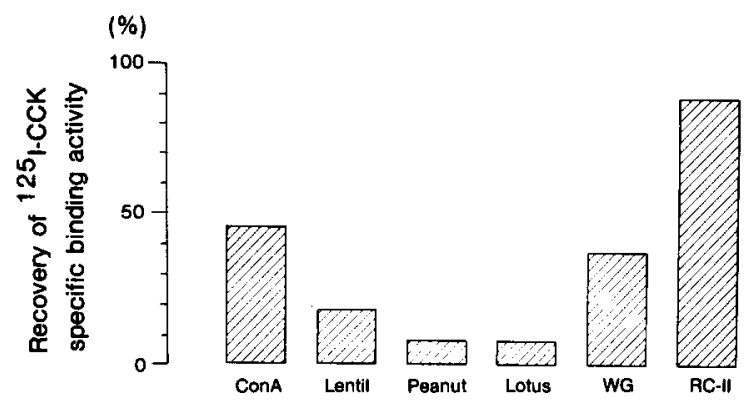

Fig. 1. Chromatography of the digitonin solubilized CCK receptors from purified rat pancreatic acinar membranes on individual lectin agarose columns. One $\mathrm{ml}$ portions of digitonin-solubilized membrane proteins were loaded on $2 \mathrm{ml}$ bed volumes of lectins-agarose. Recovery of receptors was calculated from specific binding capacities in the standard ${ }^{125} \mathrm{I}-\mathrm{CCK}$ binding assay.

bilized (final volume of $100 \mathrm{ml}$ ) with $1 \%$ digitonin. After ultracentrifugation, $85 \mathrm{ml}$ of supernatant could routinely be collected and this solubilized material showed specific CCK binding of approximately $1 \%$ of total ${ }^{125} \mathrm{I}-\mathrm{CCK}$ in the standard binding assay. The solubilized material was then diluted to a final digitonin concentration of $0.5 \%$ and loaded on an RC-II agarose column of $25 \mathrm{ml}$ bed volume (flow-rate: $0.5 \mathrm{ml} / \mathrm{min}$ ). After adsorption, the column was washed with 'solubilization buffer' containing $0.5 \%$ digitonin and finally, the semi-purified receptor fractions were eluted with 200 $\mathrm{mM}$ lactose (Fig. 2). The fractions were then assayed for specific ${ }^{125} \mathrm{I}-\mathrm{CCK}$ binding. Affinity chromatography on RC-II column resulted in almost complete quantitative recovery of the CCK binding activity, which resulted in an approximately 400 -fold purification of CCK receptors over the total homogenate (Table I).

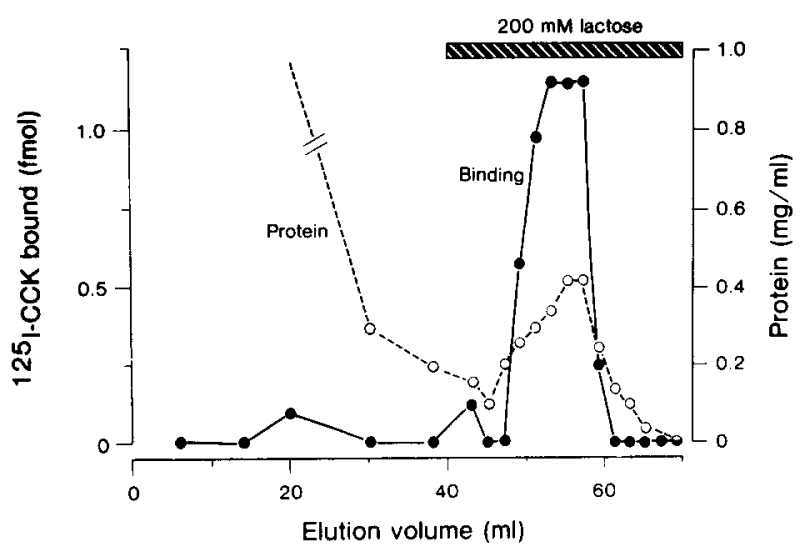

Fig. 2. Purification of CCK receptors from solubilized rat pancreas on a RC-II-agarose column eluted with $200 \mathrm{mM}$ lactose. The lectin column ( $25 \mathrm{ml}$ of settled gel) was loaded with digitonin-solubilized rat pancreas, washed with $40 \mathrm{ml}$ of 'receptor buffer', and then eluted with $30 \mathrm{ml}$ of $200 \mathrm{mM}$ lactose solution and collected as $2 \mathrm{ml}$ fractions. 
TABLE I

Summary of purification of the CCK receptor from 32 whole rat pancreases

\begin{tabular}{lccc}
\hline Step & $\begin{array}{l}\text { Protein } \\
(\mathrm{mg})\end{array}$ & $\begin{array}{l}\text { CCK binding activity } \\
(\mathrm{fmol} / \mathrm{mg})\end{array}$ & $\begin{array}{l}\text { Purification } \\
\text { factor }\end{array}$ \\
\hline 1. Solubilized pancreas & 2,000 & 0.125 & 1 \\
2. RC-II chromatography & 2.9 & 55 & 440 \\
3. AffiGel chromatography & $<0.002$ & $>10,000$ & $>80,000$ \\
\hline
\end{tabular}

The table quantitates a representative purification procedure. Specific CCK binding activities are based on the determinations of the amount of ${ }^{125} \mathrm{I}-\mathrm{CCK}$ binding in our standard radioligand binding assay (see Methods). Since receptor affinity did not change with increasing grade of purity, this approach permits a good estimate of the relative purification at each step.

\section{Purification of CCK receptor by ligand affinity chromatography}

Peak fractions $(4 \times 2 \mathrm{ml})$ from the RC-II column were then combined and adsorbed on $2 \mathrm{ml}$ of AffiGel-CCK as described in Methods. The AffiGel-CCK adsorbed $80-100 \%$ of specific CCK binding activity from the RC-II purified material. Approximately $30 \%$ of this adsorbed binding activity was routinely recovered after elution with urea and subsequent dialysis. The protein content in the dialyzed eluate was very low and could not be measured accurately; it did not exceed $1 \mu \mathrm{g} / \mathrm{ml}$, as estimated both by protein assay and the intensity of silver staining after electrophoresis. Thus, chromatography on AffiGel-CCK offered considerable further purification of the CCK-receptor with a final purification of at least 80,000 (Table I).

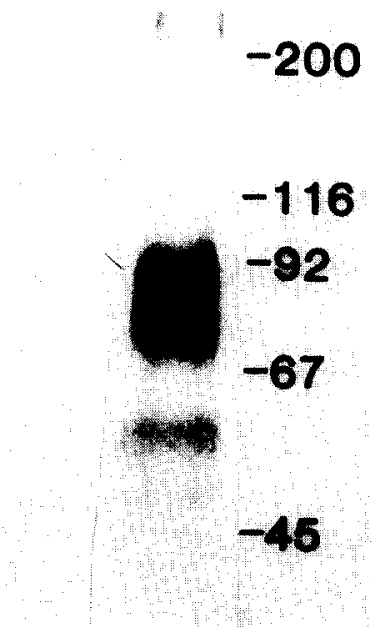

Fig. 3. Analysis of receptor purity by radioiodination, SDS-polyacrylamide gel electrophoresis, and autoradiography. Approximately $0.2 \mu \mathrm{g}$ protein eluted from AffiGel-CCK-8 was iodinated with ${ }^{125} \mathrm{I}$ and free ${ }^{125}$ I was then removed on Sephadex G-25 column. The iodinated receptors $(300,000 \mathrm{cpm})$ were boiled with $50 \mathrm{mM}$ DTT and electrophoresed on a $7.5 \%$ acrylamide gel. The figure shows a $12 \mathrm{~h}$ autoradiogram of the gel and the positions of the molecular weight markers. 


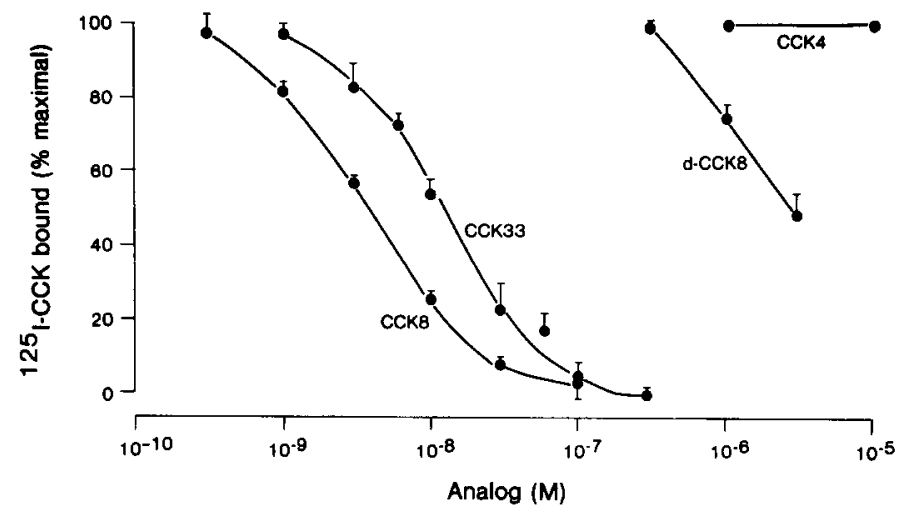

Fig. 4. Inhibition of ${ }^{125} \mathrm{I}-\mathrm{CCK}$ binding to pancreatic CCK receptors purified on AffiGel-CCK by CCK analogues. Purified receptors were incubated with $50 \mathrm{pM}{ }^{125} \mathrm{I}$-CCK for $16 \mathrm{~h}$ at $4^{\circ} \mathrm{C}$ and $\mathrm{pH} 6.5$. Varying concentrations of analogs were added as shown. Non-saturable binding was subtracted from total binding, and saturable (specific) binding was expressed as the percent of maximal saturable binding. Maximal saturable binding was $4.6 \pm 0.7 \%$. Values shown are the mean \pm S.E.M. of 3-5 experiments.

The affinity-purified material was then radioiodinated and subjected to SDS/polyacrylamide gel electrophoresis and autoradiography. The highly purified receptor protein was found to consist of two protein bands: a major band with $M_{\mathrm{r}}$ of 80,000 90,000 and a very minor band with $M_{\mathrm{r}}$ of 55,000 (Fig. 3).

\section{Properties of purified $\mathrm{CCK}$ receptors}

The ability of 4 CCK analogs, CCK-8, CCK-33, d-CCK-8, and CCK-4, to inhibit ${ }^{125} \mathrm{I}-\mathrm{CCK}$ binding to the purified receptor preparation was then examined. Competition inhibition curves of specific ${ }^{125}$ I-CCK binding by unlabeled CCK-8 and CCK-33 were sigmoidal (Fig. 4); concentrations causing one half-maximal inhibition were 4

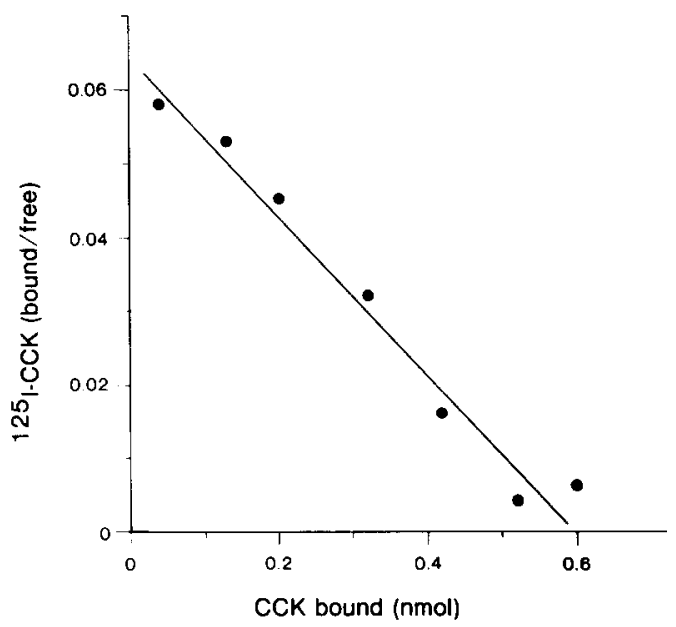

Fig. 5. Scatchard plot of ${ }^{125} \mathrm{I}$-CCK binding to pancreatic CCK receptors purified on AffiGel-CCK. Data are derived from a representative competitive binding experiment with CCK-33 under conditions specified in the legend to Fig. 4. The line is the computer fit specifying one class of binding sites with $K_{\mathrm{d}}=9.4 \mathrm{nM}$, and $B_{\max }=0.6 \mathrm{pmol} / 50 \mu \mathrm{l}$. 
nM for CCK-8 and $10 \mathrm{nM}$ for CCK-33. Desulfated CCK-8 (d-CCK-8) was approximately 1000 -fold less potent an inhibitor of ${ }^{125}$ I-CCK binding than the sulfated form of CCK-8. CCK-4 had no effect at concentrations of up to $10 \mu \mathrm{M}$. Scatchard transformations of CCK-33 binding data (Fig. 5) were best fit by computer to linear plots compatible with a single class of binding sites with $K_{\mathrm{d}}=9.4 \pm 0.7 \mathrm{nM}(n=3)$, and $B_{\max }=0.6 \pm 0.07 \mathrm{pmol} / 50 \mu \mathrm{l}$.

\section{Discussion}

In the present study we extended our previous observation that pancreatic CCK receptors could be solubilized with digitonin and that their ability to bind CCK could be retained [17]. In the present work we purified the receptor making use of two approaches. First purification of the receptor was followed and quantitated by binding of ${ }^{125} \mathrm{I}-\mathrm{CCK}$. Second, CCK covalently linked to a solid matrix was used for affinity purification of the CCK receptor. Using a two-step procedure involving immobilized lectin followed by ligand affinity chromatography, we purified the receptor to near homogeneity. Purification was approximately 80,000 fold and resulted in two identifiable protein bands under reducing conditions.

Our previous study, in which affinity-labeled pancreatic CCK receptors adsorbed on Sepharose-immobilized wheat germ lectin, indicated that the receptor was a glycoprotein containing either $N$-acetyl glucosamine and/or sialic acid residues [13]. In the present study, CCK binding activity was adsorbed and subsequently quantitatively recovered using another Sepharose-immobilized lectin, RC II. It is noteworthy that RC-II was twice as efficient in the purification of digitonin solubilized pancreatic CCK receptors than was wheat germ lectin. This observation suggests that the most predominant carbohydrate residue exposed in the receptor molecules is galactose rather than sialic acid.

By coupling CCK-8 to AffiGel we further purified the CCK receptor. The RC-IIpurified material was adsorbed on AffiGel-CCK and subsequently eluted with $5 \mathrm{M}$ urea. After radioiodination of the receptor followed by SDS PAGE and autoradiography two proteins were identified. The $M_{\mathrm{r}}$ weights of the receptor, estimated by SDS-polyacrylamide gel electrophoresis, were 80,000-90,000 and 55,000, respectively (Fig. 3). Previous reports [11-13], employing covalent cross-linking techniques to study plasma membrane-bound receptors, suggested that the main binding domain of the pancreatic CCK receptor resided in an $M_{\mathrm{r}}=76,000-85,000$ glycoprotein. In addition, another radiolabeled complex which migrated in SDS-polyacrylamide gel electrophoresis in position corresponding to an approximate $M_{\mathrm{r}}=55,000$ has also been observed in some of these studies. Thus, apparent molecular weights of the receptor in the present study are in good accordance with the results of previous studies. The relation between the two CCK binding proteins remains to be further elucidated. The possibility that they constitute non-covalently associated subunits of a complex receptor must be taken into consideration. However, another possibility is that the $55,000 M_{\mathrm{r}}$ protein is a degraded form of the larger molecule.

The binding affinity and agonist specificity of the purified receptors were deter- 
mined. These receptors showed specificity for CCK molecules with a relative potency of CCK-8 < CCK-33 < d-CCK-8 < CCK-4. These values are in accordance with data obtained with a variety of pancreatic receptor preparations including intact acinar cells [6], crude pancreatic membranes [7], purified acinar plasma membranes [17,24], and solubilized receptors [17]. Concentrations of the physiologically important CCK forms, CCK-8 and CCK-33, required to cause one half-maximal inhibition of ${ }^{125} \mathrm{I}-\mathrm{CCK}$ binding by the affinity-purified receptors were almost indentical to those causing one half-maximal inhibition of ${ }^{125} \mathrm{I}$-CCK binding by solubilized receptors [15]. Apparently, once solubilized, CCK receptors preserved their agonist specificity and affinity throughout the entire purification procedure. Scatchard transformation of binding data to purified receptor yielded linear plots, indicating a single class of binding sites with $K_{\mathrm{d}}=9.4 \mathrm{nM}$, and maximum binding capacity of $0.6 \mathrm{pmol} / 50 \mu \mathrm{l}$ in our standard binding assay. The protein concentration of the pure receptor preparation was estimated to be less than $1 \mu \mathrm{g} / \mathrm{ml}$. Thus, maximum binding capacity of the purified receptor protein is at least $12 \mathrm{nmol} / \mathrm{mg}$, a number close to that expected for a $M_{\mathrm{r}}=80,000-90,000$ receptor glycoprotein assuming a 1:1 binding stoichiometry. Uncertainties present in this analysis include the fact that migration of glycoproteins in SDS polyacrylamide gel electrophoresis often differs somewhat from their true mass and that an additional minor protein is also present. In a previous study [7], the $B_{\max }$ of the CCK receptor in crude rat pancreatic membranes was approximately $0.5 \mathrm{pmol} /$ mg protein, i.e., some 30,000 -fold lower than the $B_{\max }$ of the purified receptors. Since our starting material in the present study is 3 times more "impure" than crude pancreatic membranes (crude membrane preparations contain approximately $1 / 3$ of total pancreatic protein), the degree of purification estimated in the present study by this evaluation is also approximately 90,000 -fold.

At present, the main limitation of this receptor purification scheme is the small amount of purified receptor protein obtained. This limitation makes accurate receptor quantitation impossible and does not allow studies of protein sequence. Future work will be directed, therefore, at increasing the yield of the purification process in order to provide more detailed information on the amino acid and sugar composition of the CCK receptor.

\section{Acknowledgements}

The authors are thankful to Drs. J. Forsayeth and D.M. Hawley for helpful discussions and to Mr. D. McChesney for his technical assistance. This work was supported by NIH Grant AM32994 and the Elise Stern Haas Fund of the Mt. Zion Hospital.

\section{References}

1 Mutt, V., Cholecystokinin, isolation, structure and functions. In G.B.J. Glass (Ed.), Gastrointestinal Hormones, Raven, New York, 1980, pp. 169-221.

2 Williams, J.A., Cholecystokinin, a hormone and a neurotransmitter, Biomed. Res., 3 (1982) 107-121. 
3 Ahren, B. and Lundquist, I., Effects of two cholecystokinin variants, CCK-39 and CCK-8 on basal and stimulated insulin secretion, Acta. Diabet. Lat., 18 (1981) 345-356.

4 Szecowka, J., Lins, P.E. and Efendic, S., Effects of cholecystokinin, gastric inhibitory polypeptide, and secretin on insulin and glucagon secretion in rats, Endocrinology, 110 (1982) 1268-1272.

5 Sankaran, H., Goldfine, I.D., Deveney, C.W., Wong, K.Y. and Williams, J.A., Binding of cholecystokinin to high affinity receptors on isolated rat pancreatic acini, J. Biol. Chem., 255 (1980) 1849-1853.

6 Jensen, R.T., Lemp, G.F. and Gardner, J.D., Interaction of cholecystokinin with specific membrane receptors on pancreatic acinar cells, Proc. Natl. Sci. U.S.A., 77 (1980) 2079-2083.

7 Steigerwalt, R.W. and Williams, J.A., Characterization of cholecystokinin receptors on rat pancreatic membranes, Endocrinology, 109 (1981) 1746-1753.

8 Steigerwalt, R.W., Goldfine, I.D. and Williams, J.A., Characterization of cholecystokinin receptors on bovine gallbladder membranes. Am. J. Physiol.. 247 (1984) G709-G714.

9 Miller, L.J., Rosenzweig, S.A. and Jamieson, J.D., Preparation and characterization of a probe for the cholecystokinin octapeptide receptor, $\mathrm{N} \alpha\left({ }^{125} \mathrm{I}\right.$-desaminotyrosyl)CCK-8, and its interactions with pancreatic acini, J. Biol. Chem. 256 (1981) 12417-12423.

10 Saito, A., Sankaran, H., Goldfine, I.D. and Williams, J.A., Cholecystokinin receptors in the brain: characterization and distribution, Science, 208 (1980) 1155-1156.

11 Svoboda, M., Lambert, M., Furnelle, J. and Christophe, J., Specific photoaffinity crosslinking of $\left({ }^{125} \mathrm{I}\right)$ cholecystokinin to pancreatic plasma membranes. Evidence for a disulfide-linked $\mathrm{M}_{r} 76000$ peptide in cholecystokinin receptors, Regul. Pept., 4 (1982) 163-172.

12 Sakamoto, C., Goldfine, I.D., and Williams, J.A., Characterization of cholecystokinin receptor subunits on pancreatic plasma membranes, J. Biol. Chem., 258 (1983) 12707-12711.

13 Sakamoto, C., Goldfine, I.D. and Williams, J.A., Pancreatic CCK receptors: characterization of covalently labeled subunits, Biochem. Biophys. Res. Commun., 118 (1984) 623-628.

14 Rosenzweig, S.A., Madison, L.D. and Jamieson, J.D., Identification and localization of cholecystokinin-binding sites on rat pancreatic plasma membranes and acinar cells: a biochemical and autoradiographic study, J. Cell Biol., 99 (1984) 1110-1116.

15 Pearson, R. and Miller, L.J., Affinity labeling of a novel cholecystokinin-binding protein in rat pancreatic plasmalemma using new short probes for receptor, J. Biol. Chem., 262 (1987) 869-876.

16 Pearson, R.K., Miller, L.J., Hadac, E.M. and Powers, S.P., Analysis of the carbohydrate composition of the pancreatic plasmalemmal glycoprotein affinity labeled by short probes for the cholecystokinin receptor, J. Biol. Chem., 262 (1987) 13850-13856.

17 Szecowka, J., Goldfine, I.D. and Williams, J.A., Solubilization and characterization of CCK receptors from mouse pancreas. Reg. Pept., 10 (1985) 71-83.

18 Ponnappa, B.D., Dormer, R.L. and Williams, J.A., Characterization of an ATP-dependent $\mathrm{Ca}^{2+}$ uptake system in mouse pancreatic microsomes, Am. J. Physiol., 240 (1981) G122-129.

19 Lowry, O.H., Rosebrough, N.J., Farr, A.L. and Randall, R.J., Protein measurement with the Folin phenol reagent, J. Biol. Chem., 193 (1951) 265-275.

20 Williams, J.A., Korc, M. and Dormer, R.L., Action of secretagogues on a new preparation of functionally intact, isolated pancreatic acini, Am. J. Physiol., 235 (1978) E517-E524.

21 Sankaran, H., Deveney, C.W., Goldfine, I.D. and Williams J.A., Preparation of biologically active radioiodinated cholecystokinin for radioreceptor assay and radioimmunoassay, J. Biol. Chem., 254 (1979) 9349-9351.

22 Hunter W.M. and Greenwood F.C., Preparation of iodine-131 labeled human growth hormone of high specific activity, Nature (London), 194 (1962) 495-496.

23 Laemmli, U.K., Cleavage of structural proteins during the assembly of the head of bacteriophage $\mathrm{T}_{4}$, Nature (Lond.), 227 (1970) 680-686.

24 Sakamoto, C., Williams, J.A., Wong, K.Y. and Goldfine, I.D., The CCK receptor on pancreatic plasma membranes: Binding characteristics and covalent cross-linking, FEBS Lett., 151 (1983) 63-66. 